\title{
The terrestrial green macroalga Prasiola calophylla (Trebouxiophyceae, Chlorophyta): ecophysiological performance under water-limiting conditions
}

\author{
Andreas Holzinger ${ }^{1}$ (D) $\cdot$ Klaus Herburger $^{1}$. \\ Kathrin Blaas $^{1}$ - Louise A. Lewis ${ }^{2}$ • Ulf Karsten ${ }^{3}$
}

Received: 28 July 2016 / Accepted: 21 December 2016 /Published online: 9 January 2017

(C) The Author(s) 2017. This article is published with open access at Springerlink.com

\begin{abstract}
The phylogenetic placement of Prasiola calophylla, from an anthropogenic habitat previously shown to contain a novel UV sunscreen compound, was confirmed by analysis of its $r b c \mathrm{~L}$ gene. This alga has the capacity to tolerate strong water-limiting conditions. The photosynthetic performance and ultrastructural changes under desiccation and osmotic stress were investigated. Freshly harvested thalli showed an effective quantum yield of PSII [Y(II)] of $0.52 \pm 0.06$ that decreased to $\sim 60 \%$ of the initial value at $3000 \mathrm{mM}$ sorbitol, and $4000 \mathrm{mM}$ sorbitol led to a complete loss of Y(II). The Y(II) of thalli exposed to controlled desiccating conditions at $60 \%$ relative humidity $(\mathrm{RH})$ ceased within $240 \mathrm{~min}$, whereas zero values were reached after $120 \mathrm{~min}$ at $20 \% \mathrm{RH}$. All investigated samples completely recovered Y(II) within $\sim 100 \mathrm{~min}$ after rehydration. Relative electron transport rates (rETR) were temperature dependent, increasing from 5,10 , to $25^{\circ} \mathrm{C}$ but strongly declining at $45^{\circ} \mathrm{C}$. Transmission electron microscopy of samples desiccated for $2.5 \mathrm{~h}$ showed an electron dense appearance of the entire cytoplasm when compared to control samples. Thylakoid membranes were still visible in desiccated cells, corroborating the ability to recover. Control and desiccated
\end{abstract}

Handling Editor: Néstor Carrillo

Andreas Holzinger

Andreas.Holzinger@uibk.ac.at

1 Functional Plant Biology, Institute of Botany, University of Innsbruck, Sternwartestrasse 15, 6020 Innsbruck, Austria

2 Department of Ecology and Evolutionary Biology, University of Connecticut, Storrs, CT 06269-3043, USA

3 Institute of Biological Sciences, Applied Ecology and Phycology, University of Rostock, Albert-Einstein-Straße 3,

18059 Rostock, Germany cells contained numerous storage lipids and starch grains, providing reserves. Overall, $P$. calophylla showed a high capacity to cope with water-limiting conditions on a physiological and structural basis. A lipophilic outer layer of the cell walls might contribute to reduce water evaporation in this poikilohydric organism.

Keywords Chlorophyll fluorescence $\cdot$ Desiccation $\cdot$ Light . Photosynthesis · Temperature
Abbreviations
MAA Mycosporine-like amino acid
UVR Ultraviolet radiation

\section{Introduction}

Some green algae in the class Trebouxiophyceae (Chlorophyta), particularly members of the genus Prasiola, show a cosmopolitan distribution (Rindi 2007; Moniz et al. 2012; Heesch et al. 2016; Richter et al. 2016). The ecology of Prasiola is diverse, with some species growing in freshwater ecosystems or the supralittoral zone of marine coasts, and others occurring in terrestrial habitats (Friedmann 1969; Rodriguez et al. 2007; Rindi and Guiry 2004). Among terrestrial members, species such as Prasiola crispa ssp. antarctica even exhibit a symbiotic lifestyle with Ascomycota, forming the lichen Mastodia tessellata (Pérez-Ortega et al. 2010). In polar regions, Prasiola species prefer habitats rich in nitrogen and are found with faeces of birds such as penguins and growing in association with seagull colonies (Jackson and Seppelt 1997; Lud et al. 2001; Holzinger et al. 2006; Richter et al. 2016). Terrestrial Prasiola species are exposed to extremely harsh abiotic conditions, including strong water potential gradients between the soil surface and the 
surrounding atmosphere, resulting in regular desiccation that reduces the net production phases (Holzinger and Karsten 2013; Karsten and Holzinger 2014). In addition, terrestrial algae experience strong diurnal and seasonal fluctuations in insolation, including ultraviolet radiation (UVR). As a photoprotective mechanism under enhanced UVR, Prasiola species and related trebouxiophycean taxa synthesize and accumulate a natural sunscreen, a mycosporine-like amino acid (MAA) (e.g. Karsten et al. 2005). This compound, recently characterized from Prasiola calophylla, has a novel chemical structure composed of an oxo-carbonyl MAA (Hartmann et al. 2016). Given that prasiolin was described in $P$. calophylla, a detailed examination of the accompanying ecophysiology and cell structure/ ultrastructure of this species during desiccation is needed.

The habitat occupied by Prasiola is an example of an ecological boundary between atmosphere and surface, in this particular case, a concrete wall covered by an extremely thin layer of soil. Boundaries tend to take on emergent properties that neither bordering region possess and will tend to modulate transfer of molecules and energy from one side to the other (Strayer et al. 2003). Many physiological activities and functions of terrestrial algae are related to trapping, transmission, transformation and/or loss of molecules across the atmosphere-soil interface that is occupied by these organisms. Water uptake and water loss represent key processes for the physiological activity of terrestrial algae.

Desiccation-tolerant terrestrial algae such as $P$. crispa ssp. antarctica often exhibit morphological adaptations, including thick cell walls that protect the protoplasts from mechanical damage and the capability to synthesize and accumulate sugar alcohols as 'water-keeping' substances (Jacob et al. 1991, 1992). Any damage due to desiccation limits the distribution of these species, and they usually grow in areas where at least occasional moisture is available. Damage caused by waterlimiting conditions has recently been extensively reviewed for green algae (Karsten and Holzinger 2014; Holzinger and Pichrtová 2016). Fernandez-Marin et al. (2016) give a particular focus on the different photosynthetic mechanisms of desiccation-tolerant plant species.

The present study focused on the photophysiological and ultrastructural response of $P$. calophylla to naturally occurring water limitations in an extreme terrestrial habitat. Specifically, we investigated the (1) photosynthetic performance in response to cellular water loss (desiccation or osmotic stress) and (2) temperature dependence of photosynthesis, since the natural habitat has strong diurnally temperature changes due to varying sun exposures. Finally, we examined (3) the structural and ultrastructural features that might be responsible for the observed wide ecological tolerance. As this species is a promising model system for the physiological mechanisms of a terrestrial lifestyle, we also aimed to confirm its phylogenetic position by $r b c \mathrm{~L}$ marker analyses. An unambiguous molecular taxonomic assignment is crucial, particularly in Prasiola, where morphological variation often occurs (Moniz et al. 2012; Heesch et al. 2016).

\section{Materials and methods}

\section{Biological material}

Prasiola calophylla (Carmichael ex Greville) Kützing (Trebouxiophyceae, Chlorophyta) was isolated repeatedly from the Botanical Garden of the University of Innsbruck $(611 \mathrm{~m}$ above sea level, $47^{\circ} 16^{\prime} 2^{\prime \prime} \mathrm{N}, 11^{\circ} 23^{\prime} 34^{\prime \prime}$ E) in July 2014, July 2015 and July 2016, as described by Hartmann et al. (2016) and either transferred to Storrs, Connecticut, USA, as life sample for DNA extraction, or immediately used for photophysiological, microscopic and transmission electron microscopic (TEM) examinations as described in the following sections. A voucher specimen of the sample used for DNA extraction was deposited at the George Safford Torrey Herbarium at the University of Connecticut (CONN accession no. 273714, barcode CONN00209659).

\section{DNA sequencing and phylogenetic analysis}

Fresh P. calophylla material was extracted using the PowerPlant DNA Isolation Kit (MO BIO Laboratories, Inc., Carlsbad, CA, USA) according to the manufacturer's protocol. Two primer sets were used for amplification and sequencing of the $r b c \mathrm{~L}$ region, the PF2/PR2 primer pair (Rindi et al. 2004) and the SHF5/SHR8 pair (Heesch et al. 2012). The PCR mix consisted of $2 \mu \mathrm{L}$ of extracted DNA, $10 \mu \mathrm{L}$ of GoTaq ${ }^{\circledR}$ Green Master Mix, $0.5 \mu \mathrm{L}$ of each primer $(10 \mu \mathrm{M})$ and sterile deionized water for a final volume of $20 \mu \mathrm{L}$ in the PCR tubes. The amplification cycle consisted of an initial denaturation step at $95{ }^{\circ} \mathrm{C}$ for $4 \mathrm{~min}$, followed by 30 cycles of denaturation at $95^{\circ} \mathrm{C}$ for $30 \mathrm{~s}$, annealing at 47 or $50{ }^{\circ} \mathrm{C}$ for $30 \mathrm{~s}$ and extension at $72^{\circ} \mathrm{C}$ for $1 \mathrm{~min}$, with a final extension at $72{ }^{\circ} \mathrm{C}$ for $7 \mathrm{~min}$. The sequencing reactions were performed using ABI PRISM BigDye Terminator Cycle Sequencing Kits and run on an ABI PRISM 3730XL Analyzer (Applied Biosystems). The sequences were verified in Geneious 9.0.5 (Biomatters, Auckland, New Zealand) and then used to prepare a consensus, which was subsequently aligned manually with the published $r b c \mathrm{~L}$ sequences of related taxa. The appropriate substitution model was chosen using Modeltest in PAUP* 4.0a149 (Swofford 2002) using the Akaike information criterion (AICc). The best model selected under AIC was the general time reversible $($ GTR $)+I+$ gamma. The model parameter values were set during the search based on a pilot analysis: $\mathrm{RA}-\mathrm{C}=1.0000, \mathrm{RA}-\mathrm{G}=4.43327, \mathrm{RA}-T=1.0000$, $\mathrm{RC}-\mathrm{G}=1.4440773, \mathrm{RC}-T=8.23139, \mathrm{RG}-T=1.0000$, pinvar $=0.711319$ and gamma shape $=0.937307$ (four rate categories). A heuristic search with 100 random additions was 
performed to produce a ML tree in PAUP* using tree bisection-reconnection (TBR) branch swapping. Bootstraps analysis was performed using the same model parameters, with 100 replicates. Parsimony bootstrap analysis (1000 replicates) was performed, also in PAUP*, with TBR branch swapping. MrBayes 3.2.1 was used for the Bayesian analysis using the GTR + I + gamma model (Huelsenbeck and Ronquist 2001; Ronquist and Huelsenbeck 2003). Two independent Bayesian analyses were run for $5.1 \times 106$ generations with one cold plus three heated chains, with a subsample frequency of 1000. Convergence was determined, and trees from the initial 105 generations were discarded as burn in before producing the majority-rule consensus tree.

\section{Relative electron transport rates and temperature dependence}

Relative electron transport rates (rETR) in response to increasing photosynthetically active radiation (PAR) up to $\sim 1600 \mu \mathrm{mol}$ photons $\mathrm{m}^{-2} \mathrm{~s}^{-1}$ (PI curve) were monitored with a PAM-2500 chlorophyll fluorometer (Heinz Walz GmbH, Effeltrich, Germany) as previously described (Karsten et al. 2014; Herburger et al. 2015). Fresh algal material was harvested on a sunny day (July 2015) and PI curves $(n=4)$ were recorded at four different temperatures $(5,10,20,25$ and $45^{\circ} \mathrm{C}$ ) in a KS-2500 suspension cuvette (Heinz Walz GmbH).

rETR curves were mathematically fitted with the photosynthesis model of Walsby (1997) to derive the alpha value $(\alpha$; slope of the curve under light-limiting conditions), initial light saturation point $\left(I_{\mathrm{k}} ; \mu \mathrm{mol}\right.$ photons $\left.\mathrm{m}^{-2} \mathrm{~s}^{-1}\right)$ and maximum rETR ( rETR $\left._{\max }\right)$.

\section{Desiccation experiment and osmotic stress treatments}

Desiccation experiments were performed in a desiccation chamber as previously described by Karsten et al. (2014), with modifications. Prasiola calophylla was either collected on a sunny dry summer day (July 2015) and exposed to 20 or $60 \%$ relative air humidity $(\mathrm{RH})$ inside the chamber or collected on a rainy day during the same season and exposed to $20 \% \mathrm{RH}$. To generate water-limiting conditions via an extremely negative water potential, the samples were incubated in increasing concentrations of sorbitol $(500,1000,2000,3000$ or $4000 \mathrm{mM})$ for $2 \mathrm{~h}$ according to the well-established approach of Kaplan et al. (2013) and references therein.

\section{Confocal and transmission electron microscopy}

Confocal laser scanning microscopy (CLSM) was performed by using a Zeiss Pascal system (Carl Zeiss AG, Jena, Germany) on a Zeiss Axiovert 200 M. Chloroplast autofluorescence was visualized by exciting either fresh or desiccated thalli for $2.5 \mathrm{~h}(20 \% \mathrm{RH})$ at $488 \mathrm{~nm}$ and collecting emission above $560 \mathrm{~nm}$ (long pass filter, false color red). Corresponding bright field images were merged with autofluorescence images. Transmission electron microscopy was essentially performed as previously described (Holzinger et al. 2006). Freshly harvested samples were collected on a rainy day, mainly to illustrate the naturally fully hydrated condition, and either fixed directly or experimentally desiccated over a silica gel for $2.5 \mathrm{~h}$ prior to fixation. Briefly, samples were fixed in $2.5 \%$ glutaraldehyde in $50 \mathrm{mM}$ cacodylate buffer for $1.5 \mathrm{~h}$, rinsed and postfixed overnight in $1 \% \mathrm{OsO}_{4}$ in the same buffer at $4{ }^{\circ} \mathrm{C}$. Samples were then dehydrated in increasing ethanol concentrations, embedded in modified Spurr's low viscosity resin sectioned and poststained with $2 \%$ uranyl acetate and Reynold's lead citrate. Samples were viewed at a Zeiss Libra transmission electron microscope at $80 \mathrm{kV}$. Images were generated with a ProScan $2 \mathrm{k}$ SSCCD camera and further processed with the Adobe Photoshop Elements 11 software (Adobe Systems, San José, CA, USA).

\section{Nile red staining}

Freshly harvested P. calophylla thalli were washed in phosphate-buffered saline (PBS, $100 \mathrm{mM}, \mathrm{pH}=7$ ) and transferred to fresh PBS containing 0.1\% $(v / v)$ nile red (SigmaAldrich, Steinheim, Germany), which was previously dissolved in acetone $(0.25 \%(w / v))$. Staining was performed at an RT for $30 \mathrm{~min}$. Thalli were washed $2 \times$ with PBS and investigated with a Zeiss Axiovert 200M equipped with an OSRAM HBO 50 Q/AC L1 CZ Mercury short ARC Photo optic lamp and Zeiss filter set 15 (excitation: BP 546/12 nm; emission: LP $590 \mathrm{~nm}$ ).

\section{Statistical evaluation of the physiological data}

Photosynthetic parameters derived from rETR curves at different temperatures $\left(\alpha, I_{\mathrm{k}}, \mathrm{rETR}_{\max } ; n=4 ; p<0.05\right)$, Y(II) values $(n=4 ; p<0.01)$ under different sorbitol concentrations and Y(II) values $(n=5 ; p<0.05)$ in response to desiccation/ rehydration treatment were compared by one-way ANOVA followed by Tukey's post hoc test. Data were analysed by Origin 8.5 (OriginLab Corporation, Northampton, MA, USA).

\section{Results}

\section{Phylogenetic characterization}

The resulting $r b c \mathrm{~L}$ sequence is 1180 nucleotides in length and was deposited in GenBank under accession no. KX443662. Phylogenetic analysis of the $r b c \mathrm{~L}$ data from the Botanical Garden specimen supports designation of this alga as a member of $P$. calophylla along with 
specimens from Ireland and Japan (Fig. 1). The $r b c \mathrm{~L}$ sequence of the focal specimen is quite similar to other accessions of $P$. calophylla, differing by just 9-15 nucleotide differences, all representing synonymous changes, and the next closest species to any included sequence of P. calophylla is Prasiola fluviatilis, with 26-31 nucleotide differences (not shown).

\section{Temperature-dependent photosynthetic performance}

Samples were isolated on a sunny day $\left(26^{\circ} \mathrm{C}\right.$, cloud cover: $31 \%$, RH: $43 \%$, rainless during the last $24 \mathrm{~h})$. rETR curves recorded at 5 and $10{ }^{\circ} \mathrm{C}$ showed similar $\alpha(\sim 0.2)$ and $I_{\mathrm{k}}$ values $\left(\sim 100 \mu \mathrm{mol}\right.$ photons $\left.\mathrm{m}^{-2} \mathrm{~s}^{-1}\right)$, indicating similar kinetics (Fig. 2). At 20 and $25^{\circ} \mathrm{C}, \alpha$ decreased significantly $(p<0.05)$, while the $I_{\mathrm{k}}$ value increased significantly $(p<0.05)$ to $\sim 200 \mu \mathrm{mol}$ photons $\mathrm{m}^{-2} \mathrm{~s}^{-1}$ at $25{ }^{\circ} \mathrm{C}$ (Fig. 2). The $\mathrm{rETR}_{\max }$ values increased linearly from 5 to $25{ }^{\circ} \mathrm{C}$ (optimum) with values above $20{ }^{\circ} \mathrm{C}$, while $\mathrm{rETR}_{\max }$ was strongly inhibited at $45{ }^{\circ} \mathrm{C}$ (Fig. 2). As suggested by slightly declining rETR above $400 \mu \mathrm{mol}$ photons $\mathrm{m}^{-2} \mathrm{~s}^{-1}$, moderate photoinhibition was present at 5 and $20^{\circ} \mathrm{C}$, but absent at $25^{\circ} \mathrm{C}$ (Fig. 2).

\section{Desiccation and rehydration kinetics}

P. calophylla harvested on a sunny day $\left(28{ }^{\circ} \mathrm{C}\right.$, cloud cover: $<20 \%$, RH: $53 \%$, rainless during the last $24 \mathrm{~h}$ ) showed an initial effective quantum yield of PSII [Y(II)] of 0.57 . After $\sim 180 \mathrm{~min}$ of desiccation at $60 \% \mathrm{RH}$, the Y(II) decreased to zero within $1 \mathrm{~h}$ (Fig. 3a). After another $40 \mathrm{~min}$, thalli were rewetted, which caused a rapid increase of the Y(II) with full recovery of the effective quantum yield within $\sim 1 \mathrm{~h}$. Thalli collected on a rainy day $\left[20^{\circ} \mathrm{C}\right.$, cloud cover: $84 \%$, RH: $81 \%$, rainfall during the last $\sim 36 \mathrm{~h}$ ] and exposed to desiccation over a silica gel

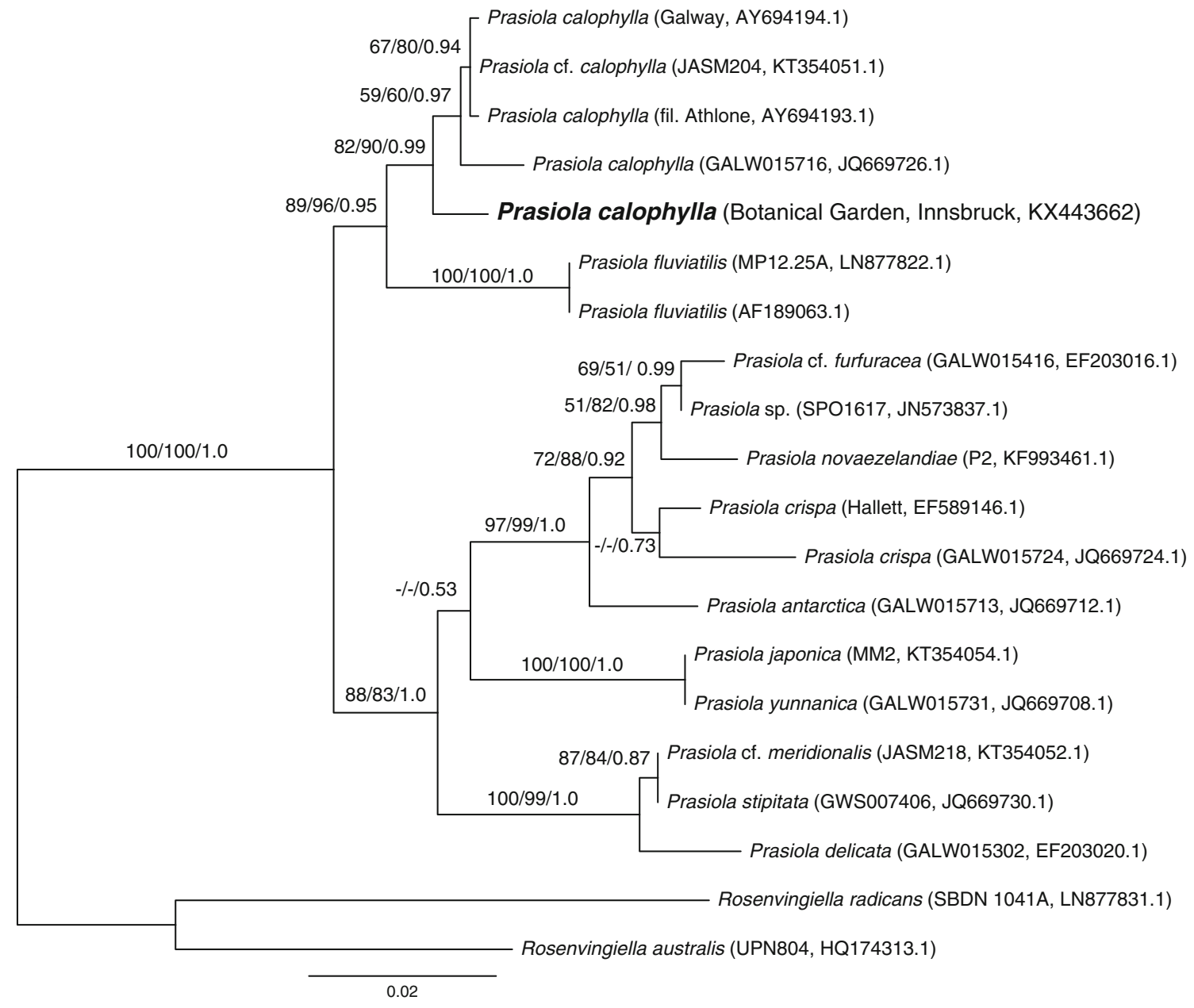

Fig. 1 Inferred maximum likelihood tree $(-\operatorname{lnL}=3430.617)$ of the $r b c \mathrm{~L}$ sequence of the Prasiola calophylla investigated in this study and sequences from related taxa. Taxon labels include strain designation (where known and GenBank accession number). Node support values include ML bootstrap values/MP bootstrap values/Bayesian Posterior Probabilities. Scale bar indicates expected number of substitutions per site 
Fig. 2 Relative electron transport (rETR) rates $(n=4 \pm \mathrm{SD})$ in response to increasing PAR up to $\sim 1600 \mu \mathrm{mol}$ photons $\mathrm{m}^{-2} \mathrm{~s}^{-1}$ at 5 , 10,25 and $45^{\circ} \mathrm{C}$. Light curve parameters are given in a temperature-dependent manner, $\alpha$ (initial slope of the curve under light-limiting conditions), $I_{\mathrm{k}}$ (initial light saturation point) and maximal rETR ( $\left.\mathrm{rETR}_{\max }\right)$. Values are means of $n=4$, and statistically significant subgroups $(p<0.05)$ are marked with lowercase letters
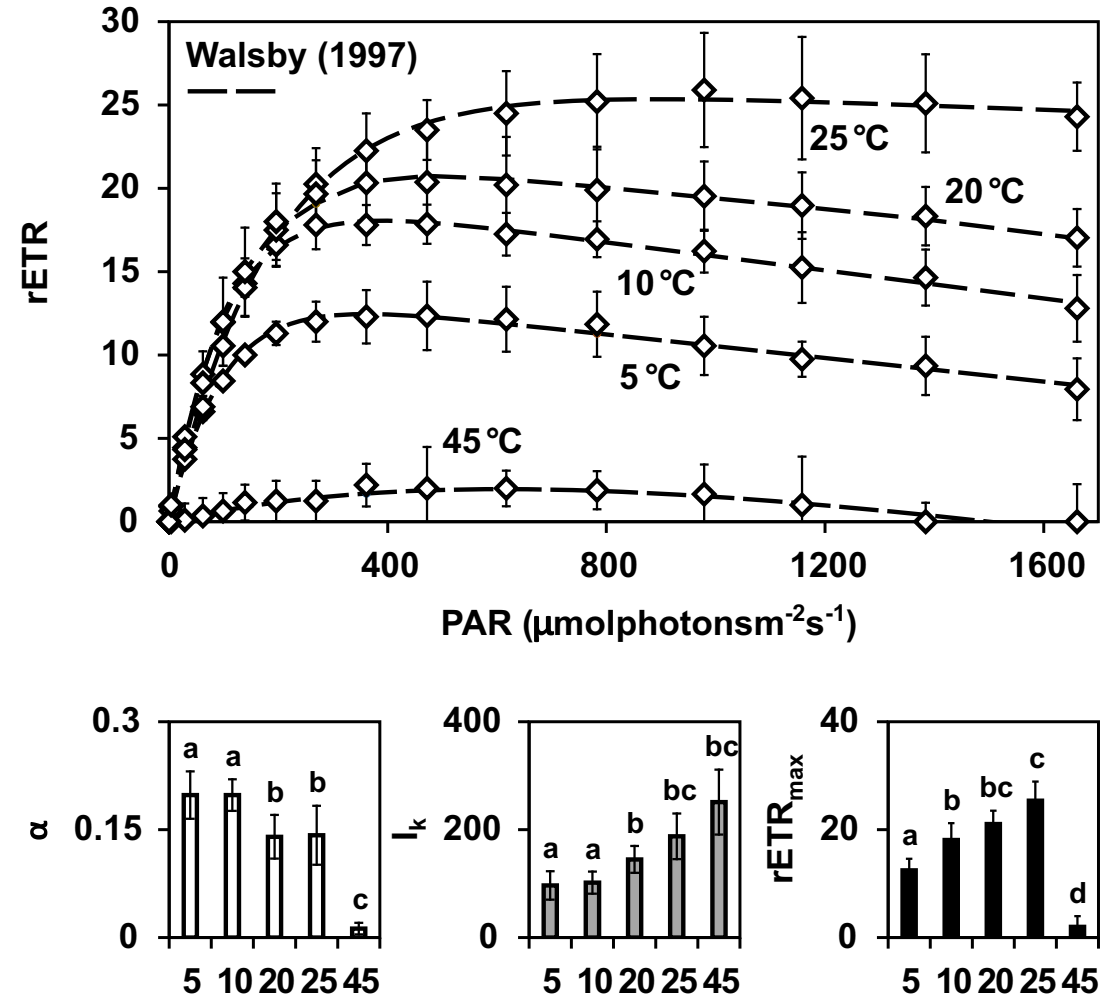

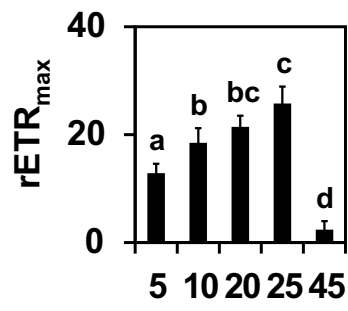

510202545 at $\sim 20 \% \mathrm{RH}$ started to decrease their initial Y(II) of 0.53 after $1 \mathrm{~h}$, whereas complete inhibition of effective quantum yield was reached after $\sim 2 \mathrm{~h}$ (Fig. 3b). Rehydration after 40 min increased the Y(II) linearly to the initial value within $\sim 2 \mathrm{~h}$. When a similar experiment (desiccation at $20 \% \mathrm{RH}$ ) was performed with samples collected on a sunny day $\left(31{ }^{\circ} \mathrm{C}\right.$, cloud cover $0 \%$, RH: $16 \%$, rainless during the last $24 \mathrm{~h}$ ), the $\mathrm{Y}$ (II) value (0.55) decreased more rapidly to zero (within $\sim 40 \mathrm{~min}$ ). However, full recovery of the photosynthetic performance still occurred within $\sim 2$ h (Fig. 3c).

\section{Water potential effects}

Thalli exposed to osmotically active sorbitol solutions up to $2000 \mathrm{mM}$ for $2 \mathrm{~h}$ showed no significantly different Y(II) values (Fig. 4). At $3000 \mathrm{mM}$ sorbitol, the initial Y(II) dropped significantly $(p<0.01)$, while at $4000 \mathrm{mM}$ sorbitol, no Y(II) signal was measurable (Fig. 4).

\section{Light and confocal microscopic observations}

Prasiola calophylla showed a mixture of uniseriate (Fig. 5a) and multiseriate (Fig. 5b) filaments of varying diameters of up to $250 \mu \mathrm{m}$. The cells were usually arranged in rows. Cells exposed to hypertonic sorbitol solutions of $1000 \mathrm{mM}$ did not show any visible change of the protoplasts (Fig. 5c). Basal uniseriate filaments exposed to $3000 \mathrm{mM}$ sorbitol were only slightly affected, with several filaments appearing similar to the control cells, with just a few filaments plasmolysed (Fig. 5d). Only incubation at $4000 \mathrm{mM}$ resulted in rounded and detached protoplasts in all cells (Fig. 5e).

When observed with CLSM, the chloroplast lobes were clearly visible by chlorophyll autofluorescence, with surface sections showing multiple lobes (Fig. 6a). Median optical sections allowed visualization of the central pyrenoid, which appeared as round structures free of chlorophyll autofluorescence (Fig. 6b). The z-stack projection clearly shows the division planes of individual cells in a thallus segment. Anticlinal divisions, which elongate the filament, are perpendicular to the thallus surface, whereas periclinal cell divisions lead to thallus broadening (Fig. 6c). Figure $6(\mathrm{~d}-\mathrm{f})$ shows thallus segments, where a bright field image (grey) is merged with an image showing the chlorophyll autofluorescence (red). Desiccation for $2.5 \mathrm{~h}$ over a silica gel resulted in an almost complete loss of the visible chlorophyll autofluorescence (Fig. 6e); the signal was, however, recovered fully, when thalli were rewetted for $2 \mathrm{~h}$ (Fig. 6f). Epifluorescence visualization of control thalli also clearly showed the chloroplast autofluorescence (Fig. $6 \mathrm{~g}$ ), and nile red staining of uniseriate filaments had reddish fluorescence on the thallus surface (Fig. 6h), also seen in mature, broader thalli (Fig. 6i). 
a

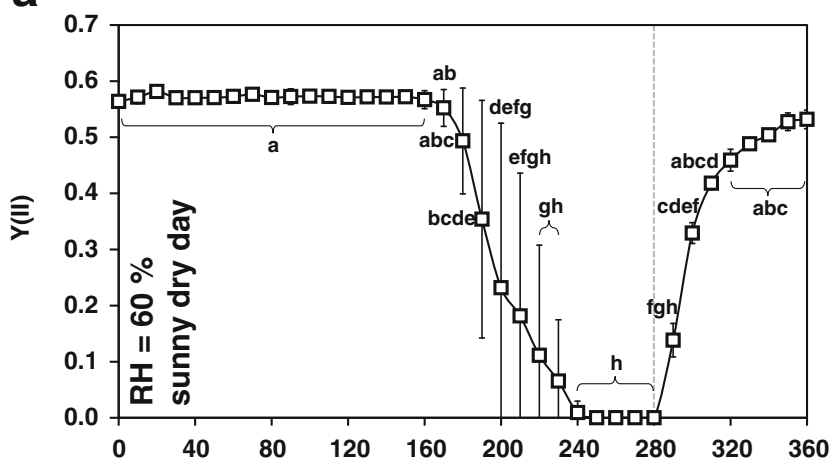

b

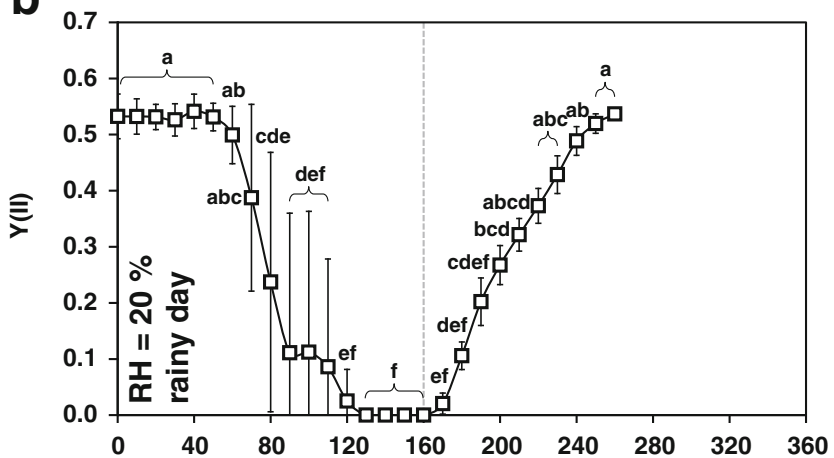

C

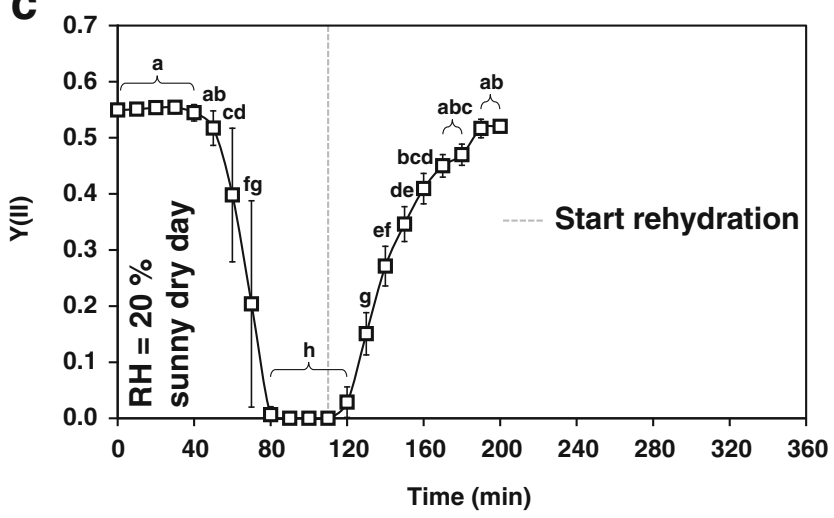

Fig. 3 Effective quantum yield of PSII $(n=5 \pm$ SD) during desiccation and rehydration. a Samples harvested on a sunny and dry day and exposed to a relative humidity (RH) of $60 \%$. b Samples collected on a rainy day and desiccated at 20\% RH. c Samples collected on a sunny day and exposed to $\sim 20 \% \mathrm{RH}$. The dashed grey lines mark the start of rehydration. Lowercase letters indicate statistically different subgroups as determined by one-way ANOVA followed by Tukey's post hoc test $(p<0.05)$

\section{Transmission electron microscopy of control and desiccated cells}

Transmission electron microscopy of $P$. calophylla cells revealed a dense cytoplasm that was virtually vacuole free (Fig. 7a-d). The terminal cells showed a thick bi-layered cell wall (Fig. 7a). The cells contained a marked pyrenoid surrounded by numerous starch grains (Fig. 7a, b). Inside the thallus, the cell walls appeared much thinner, most likely

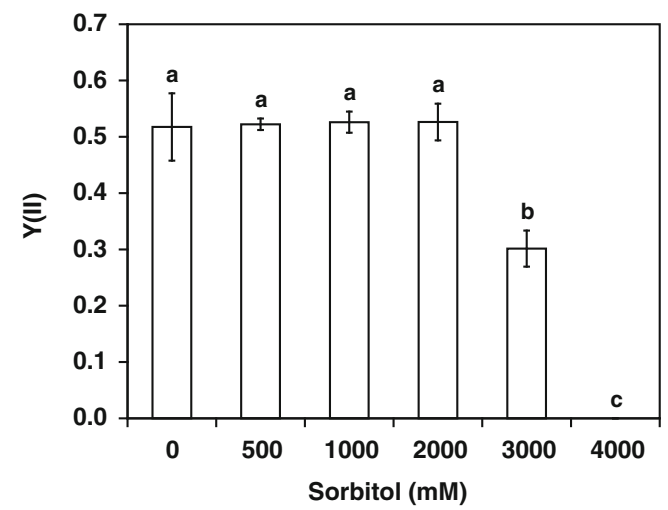

Fig. 4 Effective quantum yield of PSII $(n=4 \pm$ SD) of Prasiola calophylla exposed to increasing concentrations of sorbitol. Statistically significant differences were determined by one-way ANOVA followed by Tukey's post hoc test; significantly different subgroups $(p<0.01)$ were marked with lowercase letters

a consequence of recent cell divisions. The cells showed numerous lipid bodies in the cell periphery (Fig. 7c) and in the centre (Fig. 7d). Mitochondria and chloroplast lobes were clearly detected (Fig. 7d). Cells desiccated for $2.5 \mathrm{~h}$ showed more electron density of the protoplasts, and occasionally, the cytoplasm was markedly detached from the cell walls. The chloroplast and nucleus were still clearly visible (Fig. 8a), and the structure within the chloroplasts was very dense (Fig. 8b, c), but occasionally still showed intact thylakoid membranes (Fig. 8d). Numerous small vacuoles were visible (Fig. 8b), and large lipid bodies were found in the cell periphery (Fig. 8c).

\section{Discussion}

In the present study, the photophysiological performance of P. calophylla was investigated in response to water-limiting conditions as well as ultrastructural changes upon severe desiccation. Moreover, a phylogenetic characterization was performed based on the $r b c \mathrm{~L}$ gene analysis, confirming the previous morphological taxonomic characterization (Hartmann et al. 2016). This species is especially interesting ecologically, as an abundant occurrence of a new 324-nm absorbing UV sunscreen - termed 'prasiolin'-was isolated and chemically characterized in natural samples from the same locality (Hartmann et al. 2016). This photoprotectant likely contributes to the ecological success of $P$. calophylla in aeroterrestrial habitats.

Ephemeral Prasiola species have the capability to grow outside the aquatic milieu on bark, soil and rock and in the supralittoral zone of marine rocky shores (Rindi et al. 2007). This broad ecological amplitude makes this genus particularly interesting to study physiological adaptations to terrestrial habitats, which base either one a freshwater or a marine lifestyle. As far as known, the terrestrial members of this genus 
Fig. 5 Light micrographs of Prasiola calophylla. a Uniserate filament. b Filament consisting of four cell rows. c Thallus exposed for $2 \mathrm{~h}$ in $1000 \mathrm{mM}$ sorbitol; no visible change to untreated filament. d Uniserate thalli of the base treated for $2 \mathrm{~h}$ in $3000 \mathrm{mM}$ sorbitol; only slight rounding of the protoplasts visible. e Thallus exposed for $2 \mathrm{~h}$ in $4000 \mathrm{mM}$ sorbitol; plasmolysis is visible by slightly rounded protoplasts. Bars a-d $20 \mu \mathrm{m}$, e $10 \mu \mathrm{m}$
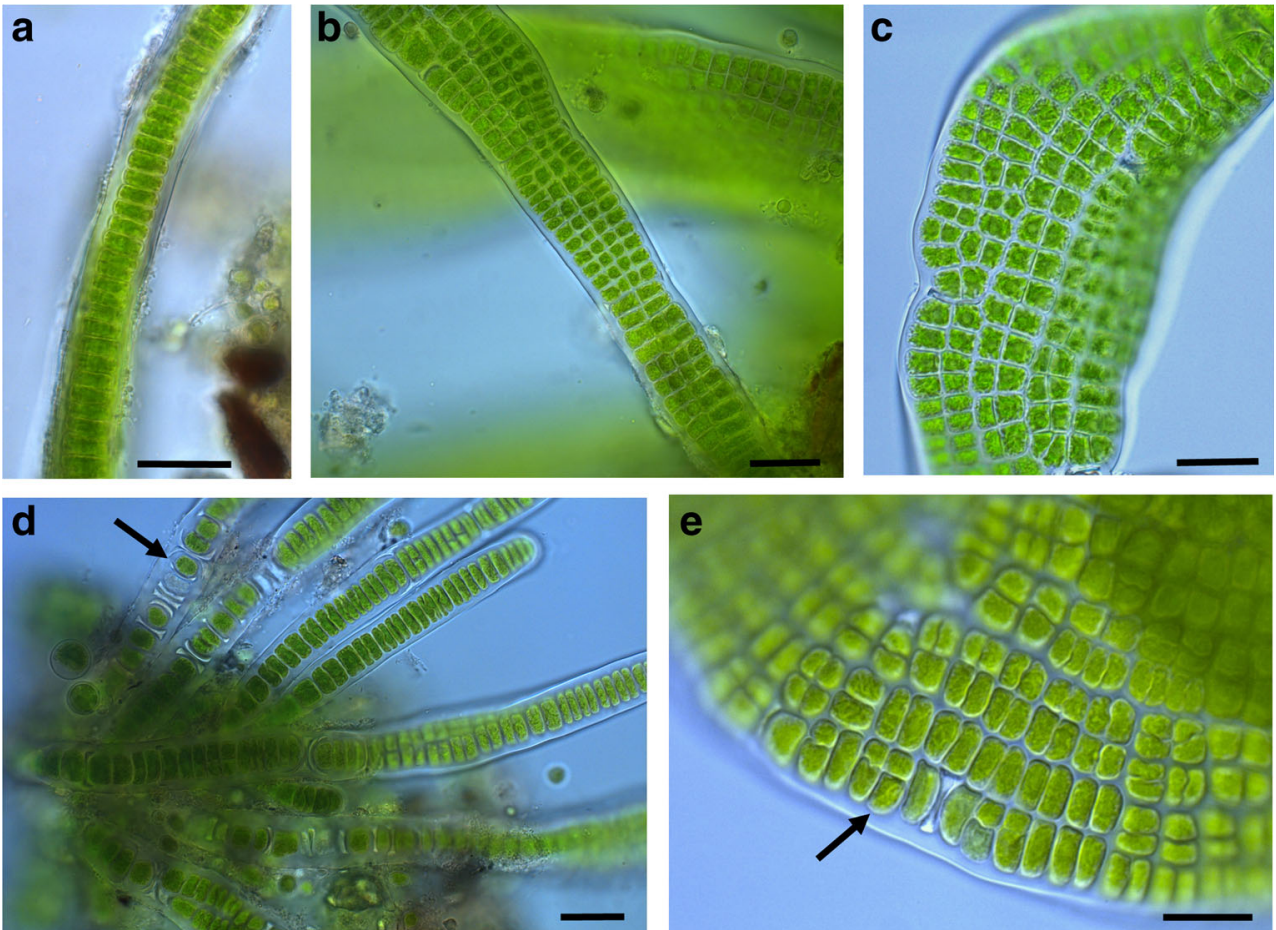

Fig. 6 Confocal laser scanning microscopy (a-f) and

epifluorescence microscopy $(\mathbf{g}-\mathbf{i})$ of Prasiola calophylla. a Cortical optical section of chloroplast lobes. b Median optical section showing the round pyrenoids free of chlorophyll autofluorescence. c z-stack projection allowing to depict the division planes of the cells. $a c$ anticlinal cell division, $p c$ periclinal cell division. d Freshly harvested thallus segment illustrating the cell walls and the chloroplast autofluorescence. e Segment of the same thallus desiccated for $2.5 \mathrm{~h}$ at $20 \% \mathrm{RH}$; chlorophyll autofluorescence (false color red) declined strongly. f Segment of the thallus rehydrated for $1.5 \mathrm{~h}$. g Control thallus segment where nile red staining was omitted. $\mathbf{h}$ Uniserate filament stained with $0.1 \%$ nile red. i Thallus segment stained with $0.1 \%$ nile red, showing reddish fluorescence labelling on the surface of the thallus (arrows). Bars $10 \mu \mathrm{m}$
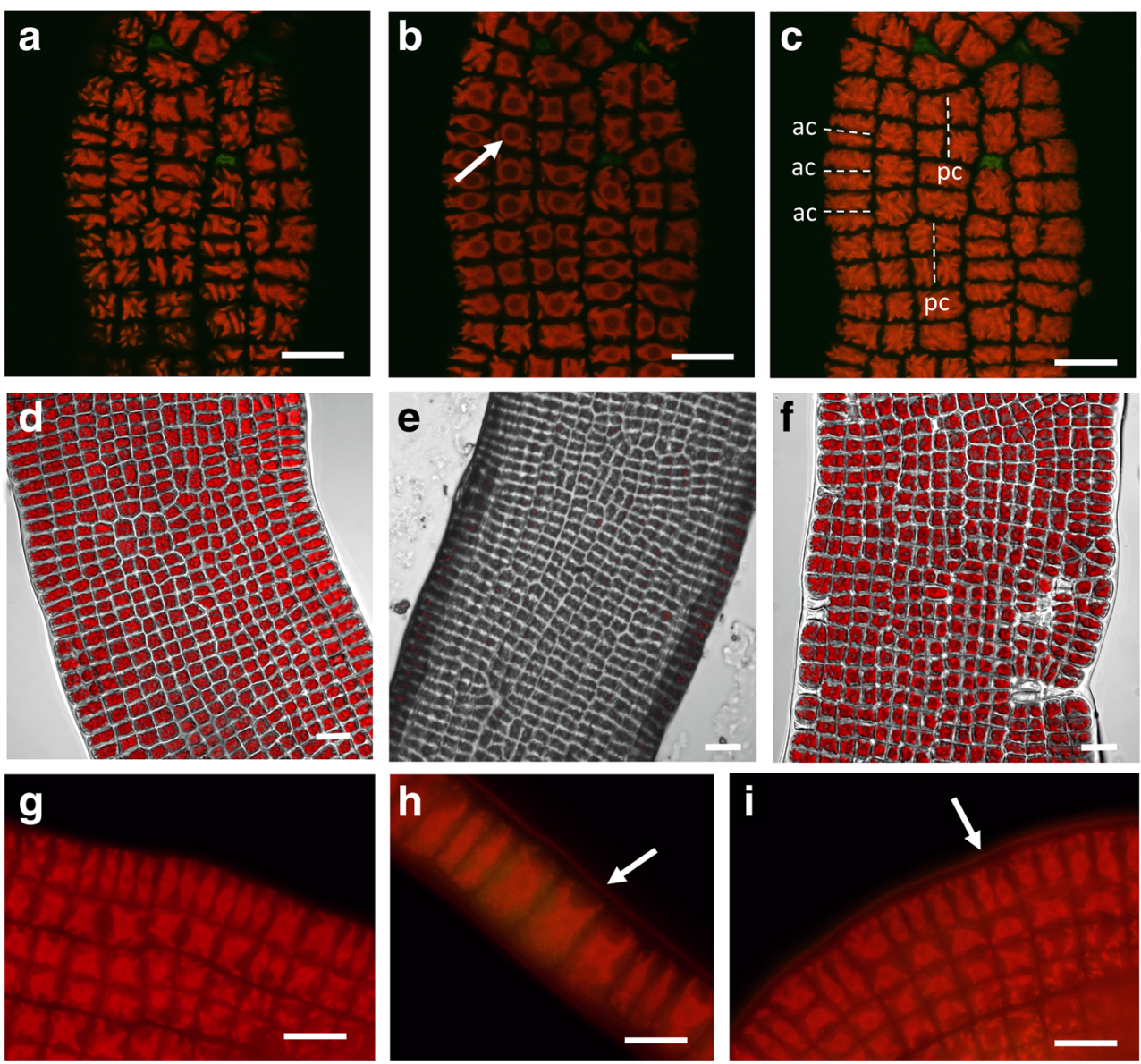
Fig. 7 Transmission electron micrographs of Prasiola calophylla control cells. a Terminal cells of uniseriate filament, dense cytoplasm and numerous starch grains around the pyrenoid: notice the bi-layered cell wall (arrow). b Top view on thallus segment, starch grains in chloroplast. c Numerous lipid bodies in the cell periphery. $\mathbf{d}$ Detail view of an area close to the nucleus, chloroplast lobe with thylakoid membranes, lipid bodies and mitochondrion. $\mathrm{Chl}$ chloroplast, $C W$ cell wall, $L$ lipid body, $M$ mitochondrion, $N$ nucleus, $P$ pyrenoid, $S$ starch grain. Bars a $2 \mu \mathrm{m}$. b, c $1 \mu \mathrm{m}$. d $0.5 \mu \mathrm{m}$
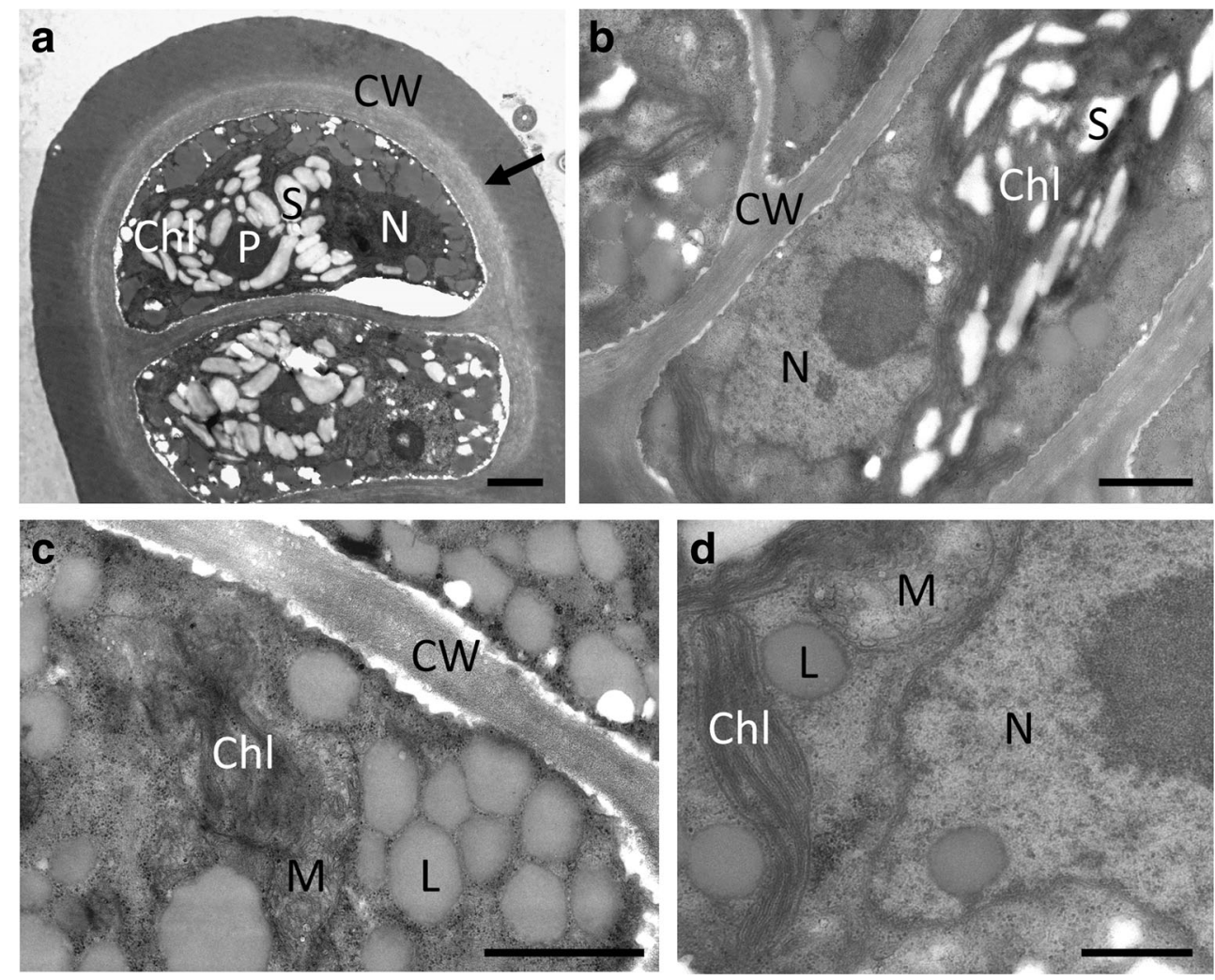

Fig. 8 Transmission electron micrographs of filed-collected Prasiola calophylla samples desiccated at $\sim 20 \% \mathrm{RH}$ for $2.5 \mathrm{~h}$. a Dense cytoplasm slightly detached from the cell wall, pyrenoid clearly visible. b Cells with homogenous cell content, small vacuoles in the cell cortex. c Detail of a cell containing large lipid bodies and starch grains. $\mathbf{d}$ Detail of the chloroplast with still intact thylakoid membranes (arrow). Chl chloroplast, $C W$ cell wall, $L$ lipid body, $N$ nucleus, $P$ pyrenoid, $S$ starch grain. Bars a-c $1 \mu \mathrm{m}, \mathbf{d} 0.5 \mu \mathrm{m}$
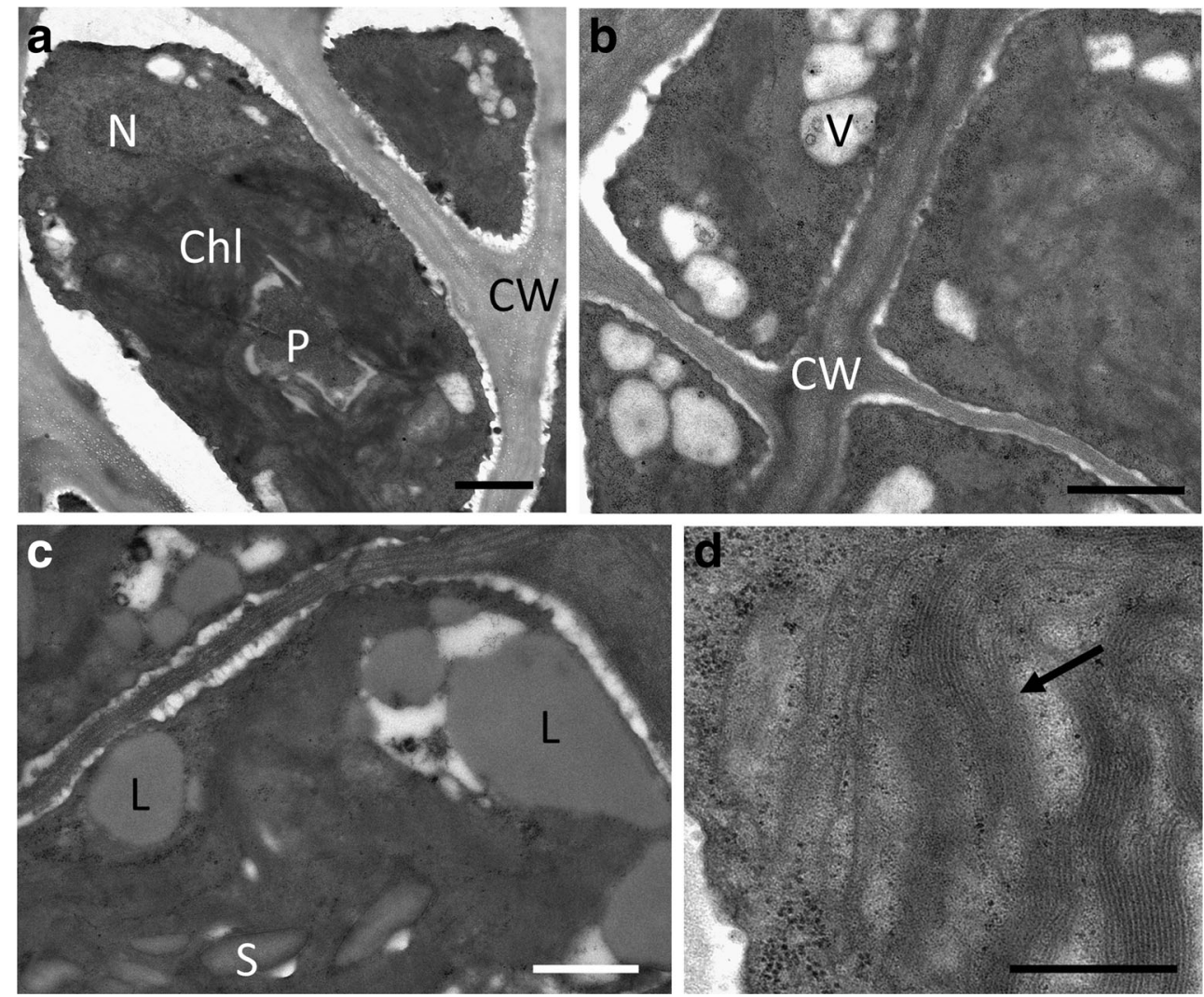
always seem to prefer nitrophilic environments shaped by bird faeces, as reported for Antarctic and Arctic taxa (Holzinger et al. 2006; Kosugi et al. 2010; Richter et al. 2016). This is confirmed for $P$. calophylla of the present study, which benefits from dog excrements (Hartmann et al. 2016). Nitrogen is essential not only for growth but also for the biosynthesis of the N-containing UV sunscreen prasiolin. A similar nitrogen dependence for the production of UV-protecting substances has been shown in the red alga Porphyra (Korbee et al. 2005).

\section{Phylogenetic position and morphological characteristics}

Kützing (1848) originally described P. calophylla (Carmichael ex Greville) Kützing from Argyll, Scotland, as dark green, curly and almost linear or ribbon shaped, with filaments gradually narrowing toward the base (Greville 1826). The species is found in cold temperate regions of the Northern Hemisphere (Guiry and Guiry 2016) and was recently reported from a wharf in Japan (Sutherland et al. 2016). Several Antarctic records of this species exist; however, Moniz et al. (2012) indicated that the $r b c \mathrm{~L}$ sequences of these specimens diverged by 38-42 bp from European specimens of P. calophylla, far greater than the variation even between the accessions from northern Europe and Japan. Moreover, a significantly different habitat (stream- and water-flushed ground distant from fertilization by birds) was described for the Antarctic collections by Broady (1989). Prasiola calophylla was so far only confirmed from northeastern Atlantic and central European regions (Heesch et al. 2016). The position of $P$. calophylla as sister taxon to $P$. fluviatilis was also confirmed by Heesch et al. (2016). Thus, the earlier reports of P. calophylla from Antarctica have to be questioned.

The chloroplast morphology was determined by CLSM, as due to the dense cytoplasmic arrangement, it was difficult to observe the structure of the chloroplasts by light microscopy alone; particularly at the CLSM images, the division planes at the sides of the thalli were clearly visible, while anticlinal cell divisions took place at the cell periphery, leading to an elongation of the blades; periclinal cell divisions were observed more toward the centre of the blades. These periclinal cell divisions lead to broadening of the thalli; this division mode is basically the same for all Prasiola sp.; however, the regularity of the occurring of periclinal cell divisions leads to different degrees of curling (Richter et al. 2016).

\section{Water-limiting conditions}

To investigate the effect of experimentally applied waterlimiting conditions, P. calophylla was either exposed to osmotically active sorbitol (Kaplan et al. 2012, 2013) or to $20 \%$ respectively $60 \% \mathrm{RH}$, resulting in desiccation. The small thalli collected in the field were densely packed with cytoplasm, exhibited a very low degree of vacuolization and required extremely high concentrations of sorbitol to induce incipient plasmolysis. In fact, plasmolysis in P. calophylla occurred only when exposed to $3000-4000 \mathrm{mM}$ sorbitol. These concentrations translate into very low water potentials of -13 to $-23.3 \mathrm{MPa}$ (Kosugi et al. 2014). Y(II) was decreased to $\sim 60 \%$ of the initial value at $3000 \mathrm{mM}$, and at $4000 \mathrm{mM}$, Y(II) was completely suppressed. Similarly, in an Antarctic P. crispa, the effective quantum yield of PSII reached zero at $3000 \mathrm{mM}$ sorbitol (Kosugi et al. 2010). In Trentepohlia aurea (Ulvophyceae) and some chlorolichens (e.g. Stereocaulon sorediiferum), however, electron flow through PSII remains active even at $4000 \mathrm{mM}$ sorbitol (Kosugi et al. 2010, 2014).

In contrast, the aeroterrestrial streptophyte green alga Klebsormidium sp. was plasmolysed at $600-800 \mathrm{mM}$ sorbitol (Kaplan et al. 2012). When compared with aquatic algae, even this value can be regarded as high. Moreover, in the late diverged streptophyte green alga Zygnema sp., which prefers hydroterrestrial habitats, incipient plasmolysis was found between 400 and $600 \mathrm{mM}$ sorbitol. These data suggest that P. calophylla exhibits a constitutively very negative intracellular osmotic potential, reducing cellular water loss due to desiccation. The major inorganic and organic solutes that might contribute to the osmotic potential have been described as potassium, phosphate, amino acids and low molecular weight carbohydrates in P. crispa ssp. antarctica (Jacob et al. 1991). Another interesting phenomenon has been observed under high salinity treatments of P. crispa ssp. antarctica, which lead to the occurrence of vacuoles that regulate the volume change of the cells (Jacob et al. 1991); this phenomenon appears contradictory at the first glance, as one would expect water loss from the vacuoles. Yet, the mechanical benefit of this capacity was described in Porpyhra umbilicalis, which uses these vacuoles to mechanically avoid separation of the protoplasm from the cell wall (Wiencke and Läuchli 1981; Wiencke et al. 1984).

\section{Photosynthetic performance}

To complement osmotic experiments, we analysed the physiological parameters by continuous measurements of the effective quantum yield in field samples which were either collected on rainy or sunny days and exposed to $\sim 20 \%$ or $\sim 60 \% \mathrm{RH}$, respectively. The desiccation kinetics revealed two factors influencing the Y(II) of $P$. calophylla under water scarcity: (1) moist conditions (i.e. rainfall, high $\mathrm{RH}$ ) prior to desiccation stress increased the maintenance of photosynthetic activity during desiccation, whereas a previous dry period caused an earlier inhibition. (2) Increasing the RH to $\sim 60 \%$ maintained the $\mathrm{Y}(\mathrm{II})$ for a longer interval despite a previous dry weather period. This suggests that short-term acclimation to dry conditions (i.e. hardening) plays only a minor role in P. calophylla to cope with low water availability, since dry weather periods do not increase the desiccation tolerance. Therefore, some 
constitutive tolerance mechanisms, such as an extremely negative osmotic potential inside the cells, might be particularly important to survive severe desiccation stress and to recover quickly after rehydration. This includes loss of PSII reaction centre activity combined with a strong reduction of both the photo-oxidation state and rereduction of PSI under dry conditions as suggested for P. crispa from an Antarctic habitat (Kosugi et al. 2010). Unlike light-induced NPQ, this desiccation-induced quenching is not restricted to light, as it also occurs in the dark (Nabe et al. 2007). It coincides with a strong reduction of fluorescence emitted between $\sim 680$ and $\sim 780 \mathrm{~nm}$ (Kosugi et al. 2010), which was also indicated in the present study by visualizing the reduction of the chlorophyll autofluorescence, illustrated by confocal laser scanning microscopy where we choose $20 \% \mathrm{RH}$, to gain maximal desiccation. However, the chlorophyll autofluorescence increased again upon rehydration, indicating the recovery of this treatment. Analogous effects, i.e. the inactivation of PSII while PSI still maintains activity, were observed in Ulva sp., where PSI remained even active after exposure to $4000 \mathrm{mM}$ sorbitol (Gao et al. 2011).

However, at the present state, we can only speculate about the extremely well performance under water-limiting conditions in P. calophylla; possible candidates for protection are, e.g. flavodiiron proteins, which are involved in cyanobacterial energy dissipation in photosynthesis; Flv1 and Flv3 proteins, functioning in the 'Mehler-like' reaction that protects PSI, have been found not only in cyanobacteria but also in green algae, mosses and lycophytes (e.g. Allahverdiyeva et al. 2015). Moreover, genes coding for flavodoxin, which is induced in cyanobacteria and green algae under osmotic-, heat- and high light stress, have been found in many Trebouxiophyceae (Karlusich et al. 2014). However, flavodoxins were lost during evolution and are lacking in streptophytic green algae and plants and tend to be lost in iron-rich habitats. In contrast, ferredoxins have been maintained throughout plant evolution. They are electron shuttlers harbouring iron-sulfur clusters and are particularly sensitive to desiccation, leading to downregulation of photosynthesis in streptopyhte green algae (e.g. Karlusich et al. 2015). However, up to now, only the draft plastid and mitochondrial genome sequences from $P$. crispa have been published (Carvalho et al. 2015); therefore, no direct evidence on the occurrence of these protection mechanisms in Prasiola is available.

\section{Ultrastructural changes}

The ultrastructural changes upon severe desiccation for $2.5 \mathrm{~h}$ corroborate our observations obtained by desiccation experiments. Untreated control cells already had a very dense cytoplasm, typical for terrestrial Prasiola sp. (e.g. Holzinger et al. 2006; Richter et al. 2016). This was even the case in the fully hydrated natural condition, as the samples for TEM were harvested on a rainy day. Interestingly, even under severe desiccation conditions ( $20 \%$ RH for $2.5 \mathrm{~h}$; we choose this treatment to illustrate the effect of the maximal water loss), some thylakoid membranes remained intact, suggesting molecular protection mechanisms as realized in other green algae (Gasulla et al. 2013). However, the preservation of the ultrastructure of desiccated samples by chemical fixation has its limitations (see Holzinger et al. 2011); for future studies, high pressure freeze fixation followed by freeze substation should be applied, but even with this technique, it is not possible to freeze desiccated samples, and an intermedium (e.g. sucrose solution) has to be used. Given the fact of the extremely negative osmotic potential, rehydration prior to the freezing process could hardly be avoided. A similar condensed cytoplasm was observed in other green algae (Holzinger et al. 2011) or mosses (Pressel and Duckett 2010). A particularly interesting observation is the occurrence of vacuoles in $2.5 \mathrm{~h}$ desiccated cells. As discussed previously for P. crispa under osmotic stress (Jacob et al. 1992), the same phenomenon also occurs under desiccation; in P. crispa, it was assumed that the vacuoles are deposition sites for ions which enter the cells. Severe desiccation goes along with changes in the ionic homeostasis that needs to be buffered to some extent, and these emerging vacuoles might be a way to compensate for these increases.

\section{Contribution of the cell walls}

Furthermore, the cell walls of $P$. calophylla withstand the mechanical stress induced by desiccation, and the cytoplasm appears only slightly retracted in some parts. However, this was also the case in the non-desiccated group. In P. calophylla, we did not observe the desiccation-induced cell wall undulations observed in Klebsormidium sp. (Holzinger et al. 2011; Herburger and Holzinger 2015) or any inner pectic layers as in Ulva compressa (Holzinger et al. 2015). The thalli of $U$. compressa and P. calophylla show some similarities, such as a flat leaf-like appearance and highly ordered arrangement of cells. However, the morphological responses to desiccation stress followed by rehydration are different in the different genera, likely due to different cell wall architectures and chemistries. Individual Ulva cells are surrounded by a flexible pectic layer, followed by several cellulose- and xyloglucanrich layers, which are embedded in an amorphous matrix consisting of pectins and ulvan (Lahaye and Robic 2007). This allows both, the protoplasts and the whole thallus to shrink and expand reversibly upon desiccation and rehydration, respectively, which minimizes structural und ultrastructural damage (Holzinger et al. 2015). In contrast, Trebouxiophyceae lack common pectic polymers found in Ulva (e.g. homogalacturonan; Domozych et al. 2012) and desiccation for up to $2.5 \mathrm{~h}$ at $20 \% \mathrm{RH}$ did not deform thalli of $P$. calophylla significantly. As shown for Prasiola japonica, Prasiola cell 
walls consist of at least four chemically distinguishable layers (Takeda et al. 1967). Interestingly, the innermost layer surrounding the protoplast contains mainly cellulose, followed by a thick and stable mannan-rich layer, while acidic polysaccharides (e.g. uronic acid) are restricted to thin layers in anticlinal walls between individual cells (Takeda et al. 1967). Embedding the protoplasts and individual cells into a rigid matrix appears to reduce mechanical deformation upon water loss and restricts structural damage to a minimum as shown for rehydrated thalli. In combination with a high water holding capacity of the protoplasts due to low osmotic pressures, structural damage as a consequence of water scarcity can be minimized. Thalli of $U$. compressa did not recover their photosynthetic performance after 90 min of desiccation at $\sim 62 \% \mathrm{RH}$, corresponding to $27 \%$ relative water content (RWC) of the thalli. Although the RWC was not measured in P. calophylla, we can estimate that in the present study, we have more severely desiccated the P. calophylla thalli, since they were exposed to $\sim 20 \% \mathrm{RH}$ for over $2.5 \mathrm{~h}$. Despite maintaining the desiccated state for at least $40 \mathrm{~min}$, all samples completely recovered.

Prasiola crispa, occurring in the littoral zone of the Antarctic sea, was able to survive a water loss of $86 \%$ after desiccation at $50 \%$ RH for 14 days (Jacob et al. 1992). In addition to very low osmotic pressure inside the protoplast, the high water holding capacity of Prasiola thalli might also be attributed to a cuticlelike layer on the thallus surface, as shown by nile red staining, a fluorescence dye commonly used to visualize neutral lipids being part of cuticles (Broehan et al. 2013). As shown for the brown alga Fucus distichus, this cuticle-like layer might consist of unsaturated fatty acids (Quadir et al. 1979). Interestingly, in P. crispa, a relation between excessive lipid bodies and fatty acids incorporated into the cell wall was assumed (Jacob 1992); since these cytoplasmic lipid bodies remain stable even after cultivation for several months in the dark, a functional role as storage compounds is unlikely. Instead, they might contain the building blocks for the cuticle-like layer. This hypothesis is supported by the observation that Prasiola species occurring in terrestrial or littoral habitats, where desiccation stress occurs frequently, usually contain abundant lipid bodies (this study; Jacob et al. 1992; Holzinger et al. 2006). Accumulating lipid bodies functioning as storage compounds in green algae is usually related to nitrogen deprivation (Pichrtová et al. 2014), which can be excluded for the organism investigated in the present study, since a high nitrogen input due to dog excrements is considered to contribute to the abundant growth (Hartmann et al. 2016). Nitrogen is also essential for biosynthesis of the Ncontaining UV sunscreen prasiolin (Hartmann et al. 2016).

\section{Temperature dependence}

Besides water availability, the temperature regime in the habitat strongly influences the photosynthetic performance of terrestrial algae, with low temperatures reducing the catalytic activity of enzymes involved in the Calvin-Benson cycle. As a consequence, electron carriers of the photosynthetic apparatus might be overreduced, which leads to a reduction of the photosynthetic performance. In $P$. calophylla, the highest rETR in response to increasing photon fluence rates occurred at $25^{\circ} \mathrm{C}$, while the activity was lower at 10 and $5{ }^{\circ} \mathrm{C}$. We have intentionally exposed samples collected on a sunny day to the various temperatures, as elevated temperatures are expected under these conditions. Obviously, $45^{\circ} \mathrm{C}$ represents a threshold for physiological activities. A similar temperature dependence was found in an Antarctic P. crispa, where the Y(II) declined below 15 and above $25{ }^{\circ} \mathrm{C}$ (Kosugi et al. 2010), pointing to similar physiological traits.

\section{Conclusion}

The present study gives a detailed overview on the physiological capabilities and ultrastructure of $P$. calophylla, a terrestrial alga that tolerates a high degree of water loss in its vegetative state. Field-collected samples showed very little sensitivity to desiccation or osmotic water reduction, enabling them to survive under extreme water-limiting conditions. The unaffected ultrastructure of the cells contributes to this high tolerance. The underlying molecular mechanisms, however, are poorly studied and, hence, $P$. calophylla would represent a perfect model system for metabolomic or transcriptomic changes under desiccation stress.

Acknowledgements Open access funding provided by Austrian Science Foundation (FWF). This study was supported by FWF grants $\mathrm{P}$ 24242-B16 and I 1951-B16 to A.H., DFG grant KA899/16-1/4 to U.K. and USA NSF award DEB-1036448 to L.L. We thank Sabrina Obwegeser, MSc., and Beatrix Jungwirth, University of Innsbruck, for excellent technical help in TEM sectioning and image generation.

\section{Compliance with ethical standards}

Conflict of interest The authors declare that they have no conflict of interest.

Open Access This article is distributed under the terms of the Creative Commons Attribution 4.0 International License (http:// creativecommons.org/licenses/by/4.0/), which permits unrestricted use, distribution, and reproduction in any medium, provided you give appropriate credit to the original author(s) and the source, provide a link to the Creative Commons license, and indicate if changes were made.

\section{References}

Allahverdiyeva Y, Isojärvi J, Zhang P, Aro E-M (2015) Cyanobacterial oxygenic photosynthesis is protected by flavodiiron proteins. Life 5 : 716-743 
Broady PA (1989) The distribution of Prasiola calophylla (Carmich.) Menegh. (Chlorophyta) in Antarctic freshwater and terrestrial habitats. Antarct Sci 1:109-118

Broehan G, Kroeger T, Lorenzen M, Merzendorfer H (2013) Functional analysis of the ATP-binding cassette (ABC) transporter gene family of Tribolium castaneum. BMC Genomics 14. doi:10.1186/14712164-14-6

Carvalho EL, da Luz WG, Fangel DL, Machado LC, da Silva AF, da Silva LFD, Macedo PE, Pereira AB, de Carvalho VF, Boldo JT, Dal Belo A, Pinto PM (2015) Draft plastid and mitochondrial genome sequences from Antarctic alga Prasiola crispa. Genome Announc 3: e01151-e01114. doi:10.1128/genomeA.01151-15

Domozych DS, Ciancia M, Fangel JU, Mikkelsen MD, Ulvskov P, Willats WGT (2012) The cell walls of green algae: a journey through evolution and diversity. Front Plant Sci 3. doi:10.3389 /fpls.2012.00082

Fernandez-Marin B, Holzinger A, Garcia-Plazaola JI (2016) Photosynthetic strategies of desiccation-tolerant organisms. In: Pessarakli (ed) Handbook of photosynthesis, 3rd Edn, Chap. 38. CRC Press, Boca Raton, FL, pp 719-737

Friedmann I (1969) Geographic and environmental factors controlling life history and morphology in Prasiola stipitata Suhr. Österr Bot Z 116:203-225

Gao S, Shen S, Wang G, Niu J, Lin A, Pan G (2011) PSI-driven cyclic electron flow allows intertidal macro-algae Ulva sp. (Chlorophyta) to survive in desiccated conditions. Plant Cell Physiol 52:885-893

Gasulla F, Jain R, Barreno E, Guéra A, Balbuena TS, Thelen JJ, Oliver MJ (2013) The response of Asterochloris erici (Ahmadjian) Skaloud et Peksa to desiccation: a proteomic approach. Plant Cell Environ 36:1363-1378

Greville RK (1826) Scottish cryptogamic flora, vol 4. MacLachlan \& Stewart, Edinburgh

Guiry MD, Guiry GM (2016). AlgaeBase. World-wide electronic publication. National University of Ireland, Galway. http://www. algaebase.org. Accessed 23 June 2016

Hartmann A, Holzinger A, Ganzera M, Karsten U (2016) Prasiolin, a new UV-sunscreen compound in the terrestrial green macroalga Prasiola calophylla (Carmichael ex Greville) Kützing (Trebouxiophyceae, Chlorophyta). Planta 243:161-169

Heesch S, Sutherland JE, Nelson WA (2012) Marine Prasiolales (Trebouxiophyceae, Chlorophyta) from New Zealand and the Balleny Islands, with descriptions of Prasiola novaezelandiae sp. nov. and Rosenvingiella australis sp. nov. Phycologia 51:217-227

Heesch S, Pazoutová M, Moniz MBJ, Rindi F (2016) Prasiolales (Trebouxiophyceae, Chlorophyta) of the Svalbard Archipelago: diversity, biogeography and description of the new genera Prasionella and Prasionema. Eur J Phycol 51:171-187

Herburger K, Holzinger A (2015) Localization and quantification of callose in the streptophyte green algae Zygnema and Klebsormidium: correlation with desiccation tolerance. Plant Cell Physiol 56:2259-2270

Herburger K, Lewis LA, Holzinger A (2015) Photosynthetic efficiency, desiccation tolerance and ultrastructure in two phylogenetically distinct strains of alpine Zygnema sp. (Zygnematophyceae, Streptophyta): role of pre-akinete formation. Protoplasma 252: 571-589

Holzinger A, Karsten U (2013) Desiccation stress and tolerance in green algae: consequences for ultrastructure, physiological and molecular mechanisms. Front Plant Sci 4. doi:10.3389/fpls.2013.00327

Holzinger A, Pichrtová M (2016) Abiotic stress tolerance in charophyte green algae: new challenges for omics techniques. Frontiers Plant Science 7. doi:10.3389/fpls.2016.00678

Holzinger A, Karsten U, Lütz C, Wiencke C (2006) Ultrastructure and photosynthesis in the supralittoral green macroalga Prasiola crispa (Lightfoot) Kützing from Spitsbergen (Norway) under UV exposure. Phycologia 45:168-177
Holzinger A, Lütz C, Karsten U (2011) Desiccation stress causes structural and ultra-structural alterations in the aeroterrestrial green alga Klebsormidium crenulatum (Klebsormidiophyceae, Streptophyta) isolated from an alpine soil crust. J Phycol 47:591-602

Holzinger A, Herburger K, Kaplan F, Lewis LA (2015) Desiccation tolerance in the chlorophyte green alga Ulva compressa: does cell wall architecture contribute to ecological success? Planta 242:477-492

Huelsenbeck JP, Ronquist F (2001) MRBAYES: Bayesian inference of phylogenetic trees. Bioinformatics 17:754-755

Jackson AE, Seppelt RD (1997) Physiological adaptations to freezing and UV radiation exposure in Prasiola crispa, an Antarctic terrestrial alga. In: Battaglia B, Valencia J, Walton DWH (eds) Antarctic communities: species, structure, and survival. Cambridge University Press, Cambridge, pp 226-233

Jacob A (1992) Physiology and ultrastructure of the Antarctic green alga Prasiola crispa ssp. antarctica subjected to osmotic stress and desiccation. Reports on Polar Research 102:1-144

Jacob A, Kirst GO, Wiencke C, Lehmann H (1991) Physiological responses of the Antarctic green alga Prasiola crispa ssp. antarctica to salinity stress. J Plant Physiol 139:57-62

Jacob A, Lehmann H, Kirst GO, Wiencke C (1992) Changes in the ultrastructure of Prasiola crispa ssp. antarctica under salinity stress. Bot Acta 105:41-46

Kaplan F, Lewis LA, Wastian J, Holzinger A (2012) Plasmolysis effects and osmotic potential of two phylogenetically distinct alpine strains of Klebsormidium (Streptophyta). Protoplasma 249:789-804

Kaplan F, Lewis LA, Herburger K, Holzinger A (2013) Osmotoic stress in the arctic and antarctic green alga Zygnema sp. (Zygnemtales, Streptophyta): effects on photosynthesis and ultrastructure. Micron 44:317-330

Karlusich JJP, Lodeyro AF, Carrillo N (2014) The long goodbye: the rise and fall of flavodoxin during plant evolution. J Exp Bot 65:51615178

Karlusich JJP, Ceccoli RD, Grana M, Romero H, Carrillo N (2015) Environmental selection pressures related to iron utilization are involved in the loss of the flavodoxin gene from the plant genome. Gen Biol Evol 7:750-767

Karsten U, Holzinger A (2014) Green algae in alpine biological soil crust communities: acclimation strategies against ultraviolet radiation and dehydration. Biodivers Conserv 23:1845-1858

Karsten U, Friedl T, Schumann R, Hoyer K, Lembcke S (2005) Mycosporin-like amino acids and phylogenies in green algae: Prasiola and its relatives from the Trebouxiophyceae (Chlorophyta). J Phycol 41:557-566

Karsten U, Herburger K, Holzinger A (2014) Dehydration, temperature and light tolerance in members of the aeroterrestrial green algal genus Interfilum (Streptophyta) from biogeographically different temperate soils. J Phycol 50:804-816

Korbee N, Huovinen P, Figueroa FL, Aguilera J, Karsten U (2005) Availability of ammonium influences photosynthesis and the accumulation of mycosporine-like amino acids in two Porphyra species (Bangiales, Rhodophyta). Mar Biol 146:645-654

Kosugi M, Katashima Y, Aikawa S, Tanabe Y, Kudoh S, Kashino Y, Koike H, Satoh K (2010) Comparative study on the photosynthetic properties of Prasiola (Chlorophyceae) and Nostoc (Cyanophyceae) from Antarctic and non-Antarctic sites. J Phycol 46:466-476

Kosugi M, Shizuma R, Moriyama Y, Koike H, Fukunaga Y, Takeuchi A, Uesugi K, Suzuki Y, Imura S, Kudoh S, Miyazawa A, Kashino Y, Satoh K (2014) Ideal osmotic spaces for chlorobionts or cyanobionts are differentially realized by lichenized fungi. Plant Physiol 166: $337-348$

Kützing FT (1848) Tabulae phycologicae, Abbildung der Tange. Wilhelm Köhne, Nordhausen

Lahaye M, Robic A (2007) Structure and functional properties of ulvan, a polysaccharide from green seaweeds. Biomacromolecules 8:17651774 
Lud D, Buma AGJ, van den Poll W, Moerdijk TCW, Huiskes HL (2001) DNA damage and photosynthetic performance in the Antarctic terrestrial alga Prasiola crispa ssp. antarctica (Chlorophyta) under manipulated UV-B radiation. J Phycol 37:459-467

Moniz MBJ, Rindi F, Novis PM, Broady PA, Guiry MD (2012) Molecular phylogeny of Antarctic Prasiola (Prasiolales, Trebouxiophyceae) reveals extensive cryptic diversity. J Phycol 48:940-955

Nabe H, Funabiki R, Kashino Y, Koike H, Satoh K (2007) Responses to desiccation stress in bryophytes and an important role of dithiothreitol-insensitive non-photochemical quenching against photoinhibition in dehydrated states. Plant Cell Physiol 48:15481557

Pérez-Ortega S, Ríos Ade L, Crespo A, Sancho LG (2010) Symbiotic lifestyle and phylogenetic relationships of the bionts of Mastodia tessellata (Ascomycota, incertae sedis). Am J Bot 97:738-752

Pichrtová M, Kulichová J, Holzinger A (2014) Nitrogen limitation and slow drying induce desiccation tolerance in conjugating green algae (Zygnematophyceae, Streptophyta) from polar habitats. PLoS ONE 9 (11):e113137. doi:10.1371/journal.pone.0113137

Pressel S, Duckett JG (2010) Cytological insights into the desiccation biology of a model system: moss protonemata. New Phytol 185: 944-963

Quadir A, Harrison PJ, DeWreede RE (1979) The effects of emergence and submergence on the photosynthesis and respiration of marine macrophytes. Phycologia 181:83-88

Richter D, Matula J, Urbaniak J, Waleron M, Czerwik-Marcinkowska J (2016) Molecular, morphological and ultrastructural characteristics of Prasiola crispa (Lightfoot) Kützing (Chlorophyta) from Spitsbergen (Arctic). Polar Biol. doi:10.1007/s00300-016-1966-2

Rindi F (2007) Prasiolales. In: Brodie J, Maggs CA, John DM (eds) Green seaweeds of Britain and Ireland. British Phycological Society, Dunmurry, pp 13-31

Rindi F, Guiry MD (2004) Composition and spatial variability of terrestrial algal assemblages occurring at the bases of urban walls in Europe. Phycologia 43:225-235
Rindi F, McIvor L, Guiry MD (2004) The Prasiolales (Chlorophyta) of Atlantic Europe: an assessment based on morphological, molecular, and ecological data, including the characterization of Rosenvingiella radicans (Kützing) comb. Nov J Phycol 40:977-997

Rindi F, McIvor L, Sherwood AR, Friedl T, Guiry MD, Sheath RH (2007) Molecular phylogeny of the green algal order Prasiolales (Trebouxiophyceae, Chlorophyta). J Phycol 43: 811-822

Rodriguez RR, Jimenez JC, Delgado CM (2007) Microhabitat and morphometric variation in two species of Prasiola (Prasiolales, Chlorophyta) from streams in Central Mexico. Aquat Ecol 41: 161-168

Ronquist F, Huelsenbeck JP (2003) MrBayes 3: Bayesian phylogenetic inference under mixed models. Bioinformatics 19:1572-1574

Strayer DL, Power ME, Fagan WF, Pickett ST, Belnap J (2003) A classification of ecological boundaries. Bioscience 53:723-729

Sutherland JE, Miyata M, Ishikawa M, Nelson W (2016) Prasiola (Prasiolales, Trebouxiophyceae) in Japan: a survey of freshwater populations and new records of marine taxa. Phycol Res 64:110 117

Swofford DL (2002) PAUP*. Phylogenetic analysis using parsimony (*and other methods). Version 4.0a149. Sinauer Associates, Sunderland, Massachusetts

Takeda H, Nisizawa K, Miwa T (1967) Histochemical and chemical studies on cell wall of Prasiola japonica. Botanical Magazine Tokyo 80:109-117

Walsby AE (1997) Numerical integration of phytoplankton photosynthesis through time and depth in a water column. New Phytol 136:189209

Wiencke C, Läuchli A (1981) Inorganic ions and floridoside as osmotic solutes in Porphyra umbilicalis. Z Pflanzenphysiol 103:247-258

Wiencke C, Knoth A, Stelzer R (1984) Changes of protoplasmic and vacuolar volume during osmotic adaptation and ion compartmentation in Porphyra umbilicalis. Hydrobiologia 116:481-484 